Etnográfica

Revista do Centro em Rede de Investigação em

Antropologia

vol. $13(2) \mid 2009$

Vol. $13(2)$

\title{
Projects of scale-making: new perspectives for the anthropology of tourism
}

Projectos de configuração de escala: novas perspectivas para a antropologia do turismo

\section{Patrick Neveling and Carsten Wergin}

\section{(2) OpenEdition}

\section{Journals}

Electronic version

URL: https://journals.openedition.org/etnografica/1125

DOI: 10.4000 /etnografica. 1125

ISSN: 2182-2891

\section{Publisher}

Centro em Rede de Investigação em Antropologia

\section{Printed version}

Date of publication: 1 November 2009

Number of pages: 315-342

ISSN: 0873-6561

\section{Electronic reference}

Patrick Neveling and Carsten Wergin, "Projects of scale-making: new perspectives for the anthropology of tourism", Etnográfica [Online], vol. 13 (2) | 2009, Online since 16 May 2012, connection on 10 February 2022. URL: http://journals.openedition.org/etnografica/1125 ; DOI: https://doi.org/ 10.4000/etnografica.1125

\section{(c) (;) (9)}

Etnográfica is licensed under a Creative Commons Attribution-NonCommercial 4.0 International License. 


\title{
Projects of scale-making: new perspectives
} for the anthropology of tourism ${ }^{1}$

\section{Patrick Neveling and Carsten Wergin}

\begin{abstract}
Scale has recently entered social anthropology as both a unit of analysis and a heuristic tool. This paper highlights the applicability to the anthropology of tourism of what has been identified as "projects of scale-making" by Tsing (2000) and respective "modes of incorporation" by Glick Schiller, Caglar and Guldbrandsen (2006). Because tourism is one of the central industries shaping present-day understandings of what is global and what is local, scale as a theoretical and methodological tool is ideally suited to study this field. Central concerns of anthropological research on tourism, such as the industry's political economy, its influence on the perception of landscapes and culture as well as the problematic notion of authenticity, are reconsidered. We argue that central shortcomings of the globalisation debate, such as a teleologically-minded futurism, euphemistic notions of economic circulation and conflations of mundane and scientific debates, shape both the tourism industry and too many anthropological studies on tourism. In light of the contributions collected in this dossier this paper instead develops an analytical framework that highlights the hidden relations of production in tourism economies and the impacts of projects of scale-making on the construction of landscapes and culture.
\end{abstract}

KEYWORDS: culture, globalisation, history, political economy, scale, tourism.

1 The papers collected in this dossier were first presented in London at the ASA conference "Thinking through tourism" in 2007. We would like to thank the organisers of this conference for granting us this possibility and all panel participants for a lively and insightful discussion. An earlier version of this introduction was presented in 2008 in a seminar of the working group "Tourism and the Oriental or 'Exotic' Other" at the Institute for Social Anthropology, Martin-Luther-University Halle-Wittenberg. We would like to express our sincere gratitude to Professor Burkhard Schnepel as well as to all participants for their insightful critique. We are very grateful to the editorial board of Etnográfica for inviting us to edit this dossier and for supporting us throughout the process. Finally, we would like to thank the authors of this dossier and particularly Marc Morell, Valerio Simoni and an anonymous peer reviewer for Etnográfica for their critical and thoughtful engagement with our ideas. Remaining mistakes are attributable only to ourselves. 


\section{A FOOTBALL WORLD CUP IN GERMANY IN THE EARLY $21^{\text {ST }}$ CENTURY}

The 2006 FIFA World Cup was an event the German public had been awaiting eagerly. City councils, federal states and the national government had made substantial efforts to prepare the country for the event: new football stadiums had been built, 3.7 Billion Euros had been invested into traffic infrastructures, 50 train stations had been refurbished, and the whole event was climate-neutral. ${ }^{2} \mathrm{~A}$ few years earlier, several German cities had competed to be selected as venues. Their hopes were high that fans and tourists would flood the tills of hotels, restaurants, shopping centres, and local crafts-markets. Only a few months before the World Cup, however, a series of violent attacks on foreigners shook the country. When a high-ranking government official suggested that foreign tourists should be provided with maps highlighting "no-go areas" - areas with high feasibility of anti-foreigner attacks by neo-fascist mobs - German media reverberated with an outcry among politicians from all parties. ${ }^{3}$ Should this industrialised and democratic country not be able to host the largest sporting event of the year because the population was a danger to visitors from other countries? More realist voices viewed the events as a potential threat to the estimated economic benefits and asked how neo-fascist strongholds, self-declared "nationally liberated areas", could be advertised as places to visit. One of the outcomes of these debates was a campaign launched by the National Committee in charge of organising the World Cup with the slogan "Die Welt zu Gast bei Freunden". ${ }^{4}$ But anxieties remained throughout the event: would the campaign suffice to tune down xenophobic voices? To cut a longer story short: the World Cup passed, and when the German team lost in the semi-finals against Italy, Italian restaurants were attacked by angry mobs in several cities. Media coverage downplayed these incidents. In the aftermath, both the government and a majority of the media proclaimed that the Germans' strong support for "their" team, expressed in swaying German banners at peaceful street parties attended by tourists from all over the world, were signs of a newly discovered "relaxed nationalism".

This brief description of probably the most important commercial event in 2006 highlights some of the main issues of concern in the anthropology of tourism within the past thirty years: host-guest relations and socio-cultural change (Greenwood 1977; Smith 1978), economic competition among

2 The German government's webpage that promoted the event gives numerous further examples of these preparations: see <http://www.wm2006.deutschland.de> (accessed 1 1/03/2009).

3 For further information on these debates see <http://www.dw-world.de/dw/article/0,2144, 1991934,00.html> (accessed 09/03/2009).

4 The English title of the campaign was: "A time to make friends". A more literal translation is: "The world as guest among friends". 
holiday destinations and the politics of development (Aspelin 1978; Clancy 2001; De Kadt 1979; Nash 2001) as well as the performative and image-centred dimension (Boissevain 1996; see also Crick 1989 and Stronza 2001 for overviews). We have chosen to introduce this dossier in a way that is unusual within tourism research: this is neither an effort to understand the perspective of hosts on guests nor the one guests have on hosts, two classic perspectives often employed in the anthropology of tourism (e.g. Boissevain 1996; Simoni 2008; Urry 1990; Waldren 1997). Particular to our concern is rather that, in the case of mega events such as the World Cup, all efforts to distinguish types of tourism, categories of tourists and mutual imaginations of hosts and guests collapse: within a few weeks, but maybe even in a single day, visitors can cover the whole range of "ethnic", "cultural", "historical", "environmental" and "recreational" tourism suggested by Smith (1978) in one of the earliest collections on the anthropology of tourism. Efforts to classify types of tourism have been numerous since then. Smith herself has established a more origin-than-activity-focused classification into "international, domestic, business related, pilgrimage or family visits" in a "revisited" version of her ground-breaking edited volume (Smith and Brent 2001: 17). Besides types of tourism, tourists themselves have been identified as the core of anthropological concern (cf. Nash 2001: 9). Entitled The Tourist: A New Theory of the Leisure Class (MacCannell 1999 [1976]), one of the central studies in the early days of research made an obvious reference to Veblen's foundational study, The Theory of the Leisure Class, published in 1899. But despite their awareness that the English verb to travel is derived from the French root travail, many authors until today implicitly follow Veblen's conception of conspicuous consumption, which leads them to regard "tourism as a mirror of society" (cf. Smith and Brent 2001: 3). ${ }^{5}$

The following considerations challenge this dualistic perspective and instead analyse tourism as one field of social and economic interaction among many others. Extending Graburn's insightful critique of an anthropological perspective that constructs tourists as "part-persons" (Graburn and BathelBouchier 2001: 149), we argue that tourism should be analysed as a global and globe-making industry. Central to the workings of this industry are hidden relations of production that stem from the ideological division into work and leisure time that obviously guides the "mirror-perspective". This perspective often builds on the idea that tourists are liminal beings who can be studied in faraway places where they have travelled to get away from everyday life (Chambers 2000: viii). Such perspectives disregard the interlinked nature of work and leisure, and more generally of production and reproduction. In the following paragraphs we neither aim to introduce new classifications into the

5 For a critique of these definitions from the perspective of residential tourism and working holidays see the papers collected in Abram, Waldren and Macleod (1997). 
anthropology of tourism nor do we intend to adjust or rework old ones. We are concerned instead with tourism as a fast-growing and diversifying industry within the world economy. In order to address how anthropology can deal with the contradictions resulting from processes of capital formation in tourism we connect anthropological debates about tourism with recent discussions on scale as an analytical tool of wider reach than, and thus covering, space, place, identity, culture, politics and economy. This approach is partly motivated by the fact that what "we gaze upon as tourists [locals and anthropologists, P.N. and C.W.] has been arranged for us in advance" (MacCannell 2001: 24).

Our account of the 2006 World Cup has shown that the predominant concern of anthropology with tourists from developed countries visiting "hosts" in less developed countries is, as argued by Nash (2001: 28-29), highly problematic. Within a northern European country like Germany, there are regions that are more and less developed. An event like the World Cup might therefore arguably be located at what anthropology and geography would call a "global scale" (Rankin 2003). But the processes of social interaction outlined in our brief summary of events could also be subdivided into a hierarchy of scales, for example "small", "large", "the local", "the city", "the region", "the nation", etc. Such divisions are often invoked when the impact of the tourism industry on holiday destinations is discussed (Gordon and Goodall 2000; Meethan 2001; Williams and Hall 2000; Young 1999). Wider questions of marginalization, subalternisation and other concerns of postcolonial critique are sometimes applied in the anthropology of tourism as well (e.g. Aitchison 2001; Coles and Timothy 2004; McKean 1978). But a different strand of critique is emphasised by Saarinen who points out, with reference to Mitchell (1984), that the "examination of tourism has generally stressed the unique case rather than the general situation or theoretization" (Saarinen 2004: 163). We argue that in order to fill this gap and arrive at more general theoretical considerations, anthropological research on tourism needs to alter its perspective on place and go beyond spatial and demographic distinctions into small or large, central or marginal. In order to attain this perspective, we follow recent reconsiderations of the concept of scale as an analytical term.

In a vivid and widely-recognised critique of the shortcomings of anthropology during the globalisation hype, Anna Tsing (2000) has introduced two conceptual tools that enable us to understand the social construction and clichés that came along with the evolutionary model of a deus ex machina understanding of global integration: "projects of scale-making" and "ideologies of scale". Although these conceptual tools sound enticing, they lack clarity and thus need to be combined with other discussions about scale. Arguing from the perspective of human geography, Manson (2008) identifies the need to integrate "realist" distinctions of absolute sizes, in other words, large and small scales, with "hierarchical" scales and "constructionist" scales within one "epistemological 
continuum" that enables social scientists to analyse these three scale-layers of human-environmental systems simultaneously. Glick Schiller, Caglar and Guldbrandsen (2006), in a critique of the identity focus within migration studies, have developed the concept of "city-scales" to show the multifarious processes that are at work since the disintegration of nation-states has rendered locational factors indispensable for income-generating activities of cities competing within the global economy. This approach is in line with Uitermark (2002) who identifies processes of "re-scaling" in the post-fordist era as changing regimes of regulation that move the negotiation of social contracts, redistribution and welfare from the national to the supra-national as well as the regional scale. Uitermark, furthermore, shows how "re-scaling" has enabled capitalist enterprises to portray themselves as either "local" or "global" depending on what benefits they want to reap from investment incentives, circumvention of environmental laws and the like.

Tourism is an arena that has so far not been discussed along the lines of such scale-based analysis. This is even more surprising because tourism is at present one of the largest industrial sectors in the global economy, generating the circulation of enormous quantities of money, labour, ideas and imaginations. With this dossier, we set out to close this significant gap. Our introduction will indicate why scale is an ideal analytical tool to study tourism along the lines of development, mobility, as well as cultural and social change. Building on a critique of the central economic theme in tourism studies, the relationship of hosts and guests, we move on to integrate the contradictions inherent in this often staged relationship into the wider projects of scale-making and ideologies of scale within the political economy and the representations of nature and culture in the tourism industry.

\section{"HOSTS AND GUESTS": AN OUTLINE OF THE POLITICAL ECONOMY OF TOURISM FROM THE PERSPECTIVE OF SCALE}

In order to attract visitors and improve the global image of the country, preparations for the 2006 World Cup in Germany focused on hospitality and efforts to contain racism. Seen from this perspective, tourism is part of the daring history of host-stranger relationships that for long has been of central concern to social anthropology. At the root of these debates, and of tourism in general, lies the effort to understand the impact of the mobility of people, capital and images (cf. Burns 1999; Cohen 2002; Edensor 2000; Hall 2005; Lash and Urry 1994; Rojek and Urry 1997). This mobility is thus not confined to the individual and his or her ability and motivation to get on the move or not, but what is especially visible in tourism is "how places and technologies enhance the mobility of some peoples and heighten the immobility of others" (Hannam 2006: 246). 
As outlined above, the notion of hosts and guests has been a core theme along which anthropologists have analysed these movements and part-time migrations. Ritual expressions of host-stranger relations frame numerous social interactions and mutual imaginations. The kula, probably the best researched of these ritual expressions, came (and comes) along with the gimwali. ${ }^{6}$ Likewise, tourism rituals that create social proximity and reciprocity come along with market transactions - although they are not as peripheral as Dalton (1965: 62) claimed for the gimwali. By now, like many social phenomena that anthropologists have brought to the attention of a wider audience, the kula is incorporated into the tourism industry and Australian companies like Coral Princess Cruises provide kula-tours with anthropologists like "Dr. Nancy Sullivan" as tour guides who indulge visitors in the techniques of exchange. ${ }^{7}$ Although already in Malinowski's days white planters were active in the Trobriands, the integration of the exchange system into wider structures changed significantly in the 1980s, when a European outsider gained control via a factory producing enough kitoum to allow him to extract most bracelets and necklaces in circulation and sell them to tourists (cf. Damon 1993 referred to in Godelier 1999: 137-138). Hidden in the present staging of the kula for tourism is the fact that, both in the past as in the present, kula transactions were and are based on economic relationships with market exchange embedded in what Parry (1986) has termed the ideology of reciprocity. ${ }^{8}$ The same ideology is inherent to tourism and its ways of constructing encounters of two modes of exchange and social practice staged to differ: the tourist's and the native's one, be it to advertise the shared holiday experience of women in Norway whose memories become a form of social capital (Heimtun 2007), the work of Texan tour guides that turns an ordinary cottage into a site of cultural heritage, the retrieval of rituals for the development of heritage tourism in such particular environments as Singapore and Hong Kong (Li 2003), or the remote Indonesian island of Alor (Adams 2004) to name but a few. In order to attract customers, the challenge for those making the offer is to portray their social settings as friendly and, in most instances, as reciprocity-based. This is where the construction of difference intersects with imagined notions of stable selves and stable others. Thus,

6 See Damon (1990), Leach (1983), and Weiner (1988) for some more recent ethnographies.

7 Although from a structural perspective, one may ask whether kula practices witnessed by Malinowski did not have a touristic dimension to them as the surplus produced in everyday activities was traded on voyages. For the Australian company see <http://www.webwombat.com.au/travel/articles/png.htm > (last visited 11/03/2009).

8 This touches issues that might be understood as "moral economies" (Busch 2000; Scott 2003). All economic transactions are of course grounded in moral considerations of those involved. Still, we prefer to see contestations of, or contests between rules of exchange and economic practice as power struggles with flexible moralities involved on all sides, rather than grounded in moral economies as prime movers. 
tourists may act as "purveyors of modern values" (MacCannell 1999 [1976]: 5) who transmit stereotypes of Orientalism's heydays. But as the other side of the coin is the fiction of rational capitalism and an enlightened Western world guiding many internationally-funded tourism promotion projects of developmental states (cf. Akyeampong 1996; Clancy 2001; Nash 2001), the tourism industry and tourists alike act as much as purveyors of an Occidentalism, in Carrier's (1992) sense, as they promote orientalist stereotypes.

This interlinked appearance of Orientalism and Occidentalism tells about the encounter of an imagined "ex-primitive" society (MacCannell 1992: 301309) and an imagined "modern" society. The first group of societies is often treated as a victim in anthropological studies and portrayed as subjected to unwanted rapid social change based on a paradigm preconditioned by classical notions of a "field" with large-scale societies (or "the global") impeding on small-scale societies (or "the local") (cf. Brenner 2001 for a critique of the spatial terminology). Focusing on the interaction of both groups, on the contrary, goes beyond such clear-cut ascriptions of victims and perpetrators and understands both as active in imaginations of one another within a field of unequal division of power. ${ }^{9}$ Without denying tourism's often negative consequences, this perspective opens up the possibility to take into account tourism's potential to encourage self-reflection on backward values persisting in host societies, like the efforts to present Germany as an open and cosmopolitan nation before and during the 2006 World Cup. How do we best get a grip on the nature of such constellations without losing sight of the underlying issues of inclusion and exclusion as well as hidden politics of representation?

As a first step, new preconditions for the "field" are necessary (cf. Gupta and Ferguson 1997; Trouillot 2003). The first of these preconditions is that, to some extent, societies and individuals have the liberty to decide on their position in the global system. These decisions frame ontologies that inform humans' ways of being in the world (Friedman 1994). They are also foundations for external ascriptions to individuals or societies by wider and more powerful social structures. The term "location" as a replacement of older conceptions of the "field" (Trouillot 2003: 123) is capable of integrating the three-layered operation of realist, hierarchical and constructed scales outlined

9 We consider this observation in line with the general argument expressed by Faubion on the obsession of both, anthropologists and their subjects, with history and the urge to position groups within historical stages (Faubion 1993: 35-36). It is beyond the scope of this paper to give an insight into the role that tourism has played in the process of self-reflection and self-invention Faubion discusses. But we hope to hint at why tourism as an economic practice, among others, encourages imaginations of historical scales based on the above-emphasised unequal division of power, obvious in the following quote: "Indian stereotypes of tourists are probably not as potentially dangerous as tourist stereotypes of Indians. After all, tourists are only tourists for a few weeks at a time, on average, and then they can go back home, while Indians are Indians for life" (Evans-Pritchard 1989: 102). 
above. Replacing "fields" with "locations" means to regard them as shaped by two processes. First, an ideological process of scale-making that often falsely positions localities according to imagined centre-periphery relations (see also Neveling forthcoming). This is exemplified in the intersection of processes of scale-making in global tourism with similar processes within nation-states and other social units, as the events of the World Cup 2006 have shown. Thus, an event of global significance turns into an incident in which scale-making, here partly nurtured by neo-fascist ideologies as a deliberate choice of life-style orientation, becomes the key factor in a counter-project: to present the German population as cosmopolitan and tolerant.

The second step goes back into the history of social anthropology, where the notion of scale has been approached from numerous perspectives. These perspectives correspond to the "epistemological continuum" introduced by Manson (2008) and outlined above. Realist notions have analysed scale in terms of population numbers and social networks which were regarded as indicators of increasing complexity (e.g. Berreman 1978). Hierarchical notions of scale have been prominent in most works on the effects of colonisation and globalisation. They have determined global versus local distinctions (e. g. Kearney 1995) but have also been analysed in more complex reworkings of centreperiphery relations as highlighted, for example, in the debates on mega-cities as centres of accumulation and decision-making (Sassen 2000; Swyngedouw 2004). The example of the World Cup 2006 helps to clarify, however, that scale, as an analytical tool, opens up a view on the twofold process of the production of political and economic inequality and culturalist stereotypes. This process is highlighted in contemporary human geography, where arguments go in favour of a distinction of "scalar structurations of social space [...] from other forms of sociospatial structuration, such as place-making, localization and territorialisation" (Brenner 2001: 603; see also Hall and Page 2002: 6ff.). Applying this observation to the field of tourism, structurations of social space need to be analysed as based on decision-making processes among tourism workers and travellers, within national and international development agendas as well as of local and multi-national tour operators. Decisions thus are made within groups, institutions, industries and other forms of social organisation and necessitate an analysis "[moving] beyond [that] of globally settled "scapes" (Tsing 2000: 345). What for several decades has been described in terms of the "size" of social units (for a summary of these efforts see Berreman 1978), today renders itself as an imaginative category used by different actors to organize the ways in which social space, people and landscapes are perceived (Glick Schiller, Caglar and Guldbrandsen 2006: 616, 625). Scale continues to be an absolute and realist category but is also made in projects that entail processes of spatial positioning in terms of infrastructural connections with the "outside" world, and of economic and social positioning in terms of 
an open or closed networking policy. Here, we follow Glick Schiller, Caglar and Guldbrandsen in their use of the term "incorporation", focusing "on processes and social relations rather than on culture, identity, or function [which] encourages the exploration of multilevel ties within and across the boundaries of nation-states and facilitates the discussion of simultaneity" (2006: 614).

Tourism is not only affected by but has an effect on spatial and socioeconomic forms of incorporation, because the industry conveys specific conceptions of values and morals as well as spatial positioning within the world economy. As a case study from a small village in western Uganda shows, consumption habits and household budgets can be altered through tourism, while networks expand via invitations of tourists to visit their home-countries in return (Lepp 2007: 881). Places like Bali, that have been integrated into tourist networks for a long time (Howe 2005; Yamashita 2003), will nevertheless portray themselves as small-scale societies which display features of historical times, regardless of whether those features have long been left forgotten or even never existed. ${ }^{10}$ As mentioned above, criteria of size for a territory's area and population are frames of reference that produce mundane conceptions of scale, "ideologies of scale", that are translated into "projects of scale-making" (Tsing 2000). Incorporating "realist" and "hierarchical" notions of scale, the position of a society can still be grounded in the number and quality of role-relationships. But this should no longer be understood in the traditional mindset of Parsonian functionalism (cf. Benedict 1966; Miller 1994). Instead, scalar positions are self-chosen and outside imposed historically traceable projects grounded in ideologies of how to live one's life. In what follows, we extend these theoretical reflections in two directions. One focuses on concepts and politics of development, political networks and arenas of production and consumption and their relation to the field of tourism. The other expands from this by focusing on the ways in which processes of scale-making arrange landscapes and culture for tourist audiences.

\section{TOURISM DEVELOPMENT AND HIDDEN RELATIONS OF PRODUCTION AS PROJECTS OF SCALE-MAKING}

As the discussion of host-guest relationships has shown, economic transactions are at the root of tourism. Many anthropological studies have engaged with the political economy of tourism by focusing on its developmental dimension in Third World countries and in peripheral regions of the Western hemisphere (Clancy 2001; Crick 1989; De Kadt 1979; Nash 2001 for a more general discussion). Anthropologists have often tried to contrast the industry's potential

10 One striking example of these latter effects of tourism is the "de-development" of local villages in Luxor, Egypt (Mitchell 1995). 
to generate income and increase Gross National Products with its adverse effects on local populations (cf. Aspelin 1978; Smith 1978). The intersection of economic changes in the countries of origin with developmental projects in Third World countries has often been neglected instead (cf. Nash 2001 for a discussion of the exceptions). As the four papers collected in this dossier are all concerned with the intersection of these developmental dimensions of tourism, the following argument establishes a general framework to understand this mutual process of global integration and shows how the hidden relations of production in global tourism can be unveiled when scale is introduced as an analytical tool.

The era following World War II was, in Western countries, shaped by a long period of relatively peaceful industrial relations. Key factors leading to the decline in class-struggle-based interactions were central to the social contracts framing this era: tripartite agreements between political parties, private sector groups and trade unions came in concert with the promise of mass consumption (Silver 2003). Tourism had been an activity of elites in the period from 1840 until 1940 and became part of the mass consumption package promised in the new social contracts after World War II. ${ }^{11}$ The industry worked for both hosts and guests as a "machine of manifestations". On the one hand, tourists from the core regions found themselves in a privileged position in the places they visited. As they gathered a "staged idea" of societies exhibiting a much higher degree of social and economic inequality (cf. Nash 2001: 28-42), their awareness of Western superiority changed. On the other hand, the inhabitants of holiday destinations became aware of the possibilities of worldwide travel as leisure-time activity. For several decades, the images created and sold in global tourism were an integral part of the hierarchical ordering of the world into "developed" and "underdeveloped" nations, both on the global scale of "First" and "Third" World distinctions and in the rural vs. urban dichotomy within the Western world, where the bulk of tourism was centred (cf. Chambers 2000; Clancy 2001). In recent years, the global flows of foreign direct investment have no longer moved unidirectionally from "industrially advanced" regions to "underdeveloped" or "developing" regions. Indian or Chinese companies have become regular buyers of bankrupt Western (travel) companies like $\mathrm{P} \& \mathrm{O}$ ferries. These changes have led some scholars to declare the end of Western-led development as well as that of a highly unequal division of

I1 Some authors claim that modern tourism emerged in the mid-nineteenth century when the first international travel agencies like Thomas Cook were founded (cf. Chambers 2000: 12-15). Others argue also on the basis of a democratisation of travel, and highlight the mushrooming of seaside resorts in England (Urry 1990: 16-39). In our view, these resorts were only open to a working class elite and can thus still be classified as elite tourism. Furthermore, as Urry himself argues (1990: 42-45), tourism again changed significantly after World War II and it was this period of change that led to the emergence of international mass tourism. 
economic bargaining power and access to technology (Sidaway 2007). In the global tourism economy, the numbers of Indian, Chinese or Brazilian customers are increasing in similar ways. But the majority of tourists still comes from Western countries and most of the income generated from tourism stays in these countries (cf. Duval 2007). Most of the arrangements tourists, workers and anthropologists gaze upon have been generated by projects of development and modernisation. While these projects have been analysed extensively along the lines of national economic policies targeting the agricultural and non-agricultural sector (see Edelman and Haugerud 2005; Ferguson 2005; Leys 1996 for overviews), planned development in popular holiday destinations and changes in the ways of life for large parts of the population have not been researched extensively (cf. Montanari and Williams 1995; Nash 2001).

As argued above, the images and infrastructures created to generate development via tourism are grounded in ideologies of scale distinguishing "traditional" and "modern" as well as "small-scale" or "large-scale" societies (cf. Clancy 2001; MacCannell 1992). While modernisation theory has lost its "seductive" qualities, the concept of globalisation has served as a replacement, with teleological and normative assumptions likewise at its core (Tsing 2000: 328). Arguing for an understanding of modernisation and globalisation as "ideologies of scale", Tsing identifies three blind alleys in the social sciences. Notions of "futurism" that assume a newness of global integration (for similar arguments see Baca 2005, Neveling 2006), "conflations" summarising all "globe-making projects" into one frame of change, and "circulation" as a concept replacing the Marxist notion of a "penetration" of capitalism with "images of the healthy flow of blood in the body and the stimulating, evenhanded exchange of the marketplace" (Tsing 2000: 334-336). Tourism trends follow the ups and downs of the global economy, and because tourism is one of its integral parts anthropological research can benefit from the three directions of analysis outlined above. In the realm of circulation, an interpretation along the path of "rape-like" penetration of local communities by tourism industries seems to prevail whereas the inequalities within the "victimised" societies are overlooked because tourism was often identified as a one-way street of imperialism and neo-colonialism (cf. Crick 1989; Nash 1989; Schlehe 2003). Thus, whereas in other domains, cultural appropriations in the field of mass consumption (Clifford 1997; Miller 1994) were celebrated, tourism was the arena where the evil West still hit hard on the powerless "natives" and commodified "their" culture (see MacCannell 2001 for an overview of this position). Instead, the "hidden relations of production" (Tsing 2000: 337) within tourism are to be discovered elsewhere.

As outlined above, the circulation of tourists after 1945 was, to a large extent, triggered by Keynesian social contracts in Western industrial societies. Mass tourism on an island like Mallorca, as Marc Morell's paper in this 
volume shows, brought along urbanisation in the 1960s and declined with the global oil crisis of 1973 (cf. Juardao 1990, referred to in Nash 2001: 29, for a similar study of the Costa del Sol). Morell shows how a neighbourhood in the historic centre of the island's capital has been gentrified over a period of more than twenty years. This gentrification is part of the wider tourism development policies of the Mallorcan government that are supported by the Spanish state and the European Union and carried out in public-private partnerships. The position of the neighbourhood is defined by the phases of tourism development on the island and the government's development policies that shift from an interest in post-1945 welfare-based social contracts to a strong support for private developers restructuring the neighbourhood and altering the composition of its inhabitants. Because the idea of fer barri [making neighbourhood] is deeply rooted in Mallorca, it can be understood as a local way to delineate projects of scale-making. The city council, private sector development companies, but also the old inhabitants of the neighbourhood opposing gentrification and even the squatter movement operate on the basis of fer barri, meaning they all claim to know what makes a proper neighbourhood. Morell introduces a group of long-term inhabitants who meet regularly in a local grocery and entertain informal networks of mutual support and gossiping. In times of crisis, when gentrification threatens the supply of housing, the shop's owner uses these channels to jump scales (Smith 1992). Because all actors working the neighbourhood scale in Es Barri, the name Morell chooses for the quarter, pursue commercial interests, the neighbourhood scale becomes both an ideological scale where contests over economic morality take place and a project of scale-making that opens up a market to cater for customers. The "economic moment" here requires more than its own "outside" (i.e. parallel political or institutional organisations) in order to function (Swyngedouw 2004: 32). The entangled nature of claims to proper neighbourhood-making and competing projects of scaling the old town instead show that realist, hierarchical and constructivist notions of scale are simultaneously at work in this Mallorcan neighbourhood. It is thus not one large structure impeding on a smaller one but a network of alliances either supporting or opposing gentrification that engages in the contest to fer barri. A thorough analysis of the historical emergence and alterations of these alliances is necessary in order to avoid "conflations" that would summarise these diverse and contested arenas of power into one frame.

Juraj Buzalka's contribution on ethnicity and tourism in southeastern Poland is concerned with a similar issue. The consecutive re-invention of the supposedly pagan "Kupaly Night" ritual in a village and in the regional capital Przemyśl is described by those involved as an emerging contest over authenticity. But "Kupaly Night" itself is anything but authentic, as the ritual was first re-invented in the late $19^{\text {th }}$ century. Because Eastern European socialist 
states built on Marx's notion of historical progress to educate local populations in the stages of human development, it is no wonder that after 1989, all over Eastern Europe, self-reflection on historical roots mushroomed. ${ }^{12}$ The "Kupaly Night" ritual is an example of such projects of scaling history that root the respective location in whatever pre-colonial, pagan or pre-civilised past, and thus resemble the socialist projects of scaling history in particular settings. Buzalka describes how the festival was shifted to the provincial capital and how the owners of hostels and bars in the village of Posada lamented commercialisation and the loss of authenticity. He thus shows how notions of originality and "authenticity" can quickly emerge when a business is taken away from the "hosts" under a changing national development agenda. The festival was integrated into a wider regional setting of EU politics that offer the choice between ethnicity-based regionalism and the re-scaling of ethnicity to a celebration of European multiculturalism. Looking at processes of re-scaling (Uitermark 2002) as both an option to regionalise and to "cosmopolitanise" a holiday destination, Buzalka's study indicates that there is no contradiction between the politics of connection and disconnection, which Green, Harvey and Knox (2005) find with reference to scalar differences in EU-funded initiatives to promote information and communication technologies. Instead, two modes of incorporation are offered in EU policies. The history of southeastern Poland serves as a vehicle for the futurism this institutional framework provides, namely the notion of authenticity.

In a similar vein, Valerio Simoni, in a description of the marketing of Cuban cigars, shows how the socialist government, informal dealers and rural farmers all have their ways of framing this commodity within competing projects of scale-making in order to bring the tourists' money their way. Simoni's case study is concerned with manifold hidden relations of production. Cigars on the Cuban market become available for tourists of all social strata, due to the relatively weak position of the island in the global economy. Thus, a commodity that itself was central to the global project of colonialism, including the extraction of luxury goods from colonised territories, has now become an object of mass-consumption, like other tobacco products, coffee, or tea have become in earlier times. But the (tourist) masses are not as flexible as the mobility of capital. They are confined to Cuban soil no matter whether their intention is to buy "world-class" cigars at "socialist", "workers" or "fair" prices, or to "roll their own" natural cigar under the auspices of local farmers in the valley of Viñales. One may argue that the US embargo is the project of scalemaking that actually makes Cuban socialism work and Cuban cigars affordable for the masses, because the embargo secures favourable exchange rates for US-dollars. The establishment of convertible currencies in the global economy 
has been discussed widely (Gregory 1997; Polanyi 1957), but what Simoni's paper shows is how money and a commodity of worldwide reputation create a series of formal and informal encounters between tourists and locals along the chain of cigar production. These competing projects of scale-making can neither be understood as a "rape-like" penetration of a region by the capitalist world economy nor as the image of healthy flows criticised above. Instead, in a series of ill-matched encounters numerous projects of scale-making with particular and standardised formal and informal frames are introduced, all making reference to the wider process of circulation of Cuban cigars scaled as a luxury commodity.

Undine Frömming describes the appropriation of the Kilimanjaro in colonial and post-colonial times. Tourism here is marketed as a different type of luxury, the luxury of natural sensations and experiences of the self. Like the Cuban street dealers and rural farmers, the Chagga population of 1,5 million people inhabiting the Kilimanjaro region in Tanzania provides a substantial part of the tourism industry's labour force. They are not small in numbers, but the position of the lower classes of Chagga society within the economy is relatively weak. Why this is so can be understood when the trajectory of the Tanzanian developmental state is contrasted with the Cuban one. In the latter case, neither the tobacco farmers nor the street vendors are the main targets of the nation-state's development goals. And although the Cuban cigar is an emblem of the island like the Kilimanjaro is for Tanzania, the tourism economy seems to be a lot more liberal and embedded into the Cuban social settings discussed by Simoni. One hidden relation of production here is played out in "Cuban culture" and thus by Cubans as economic actors who become commodities of the tourism industry themselves. There is hardly a place that could compete with Cuba in terms of salsa, cigars and socialism and there is also hardly a place that could compete with the natural wonders of the Kilimanjaro. The crucial point is that both notions of "culture" marketed here are grounded in the Janus-headed history of European enlightenment. Unlike Cuba, the voices of socialism that dominated Tanzania at the time of independence are long gone. Tanzanian nation-building, as Frömming shows, included a naming ceremony the postcolonial government held on the mountain's peak, that resembled the German colonial naming of the mountain in the 19th century. In Frömming's example, the nation-state, only recently re-discovered as a relevant social actor by anthropologists (cf. Chalfin 2006, among others), plays a significant role as a motor for developing the tourism industry within an alternative project of modernity.

As we have argued in the first paragraphs of this section, it is therefore advisable to analyse tourism as one of the strategies employed by the state to generate export-led development. In order to do this, the historicity of the concept of development must be reframed in relation to tourism. During the 
heydays of development, the 1960s and 1970s, in many countries of the world tourism was not high on the agenda. Like the Kilimanjaro region, other countries that are among the main tourism destinations worldwide today promoted manufacturing-based export-led development in the early 1970s (see Neveling 2006; Schnepel 2008a, 2008b for the case of Mauritius). Tourism instead often moved up on the developmental agenda when efforts to establish manufacturing industries ended or failed. As in the case of Mallorca, post-industrial urban areas are turned into heritage sites by the developmental state of the early $21^{\text {st }}$ century. These policies indicate that development is not at its end (Ferguson 2005, with exceptions) but has numerous continuities in the project of globalisation (cf. Ziai forthcoming). At the same time, relations of production in the economy of tourism remain veiled behind the curtains of paradiseisland images sold through a successfully blurred tourist's gaze. To lift these veils and highlight the continuities within the projects of colonialism, imperialism, modernisation and globalisation sheds light on what Tsing (2000) has identified as "the hidden relations of production" of the globalist era.

\section{"LANDSCAPES" AND “CULTURE" AS IDEOLOGIES OF SCALE IN GLOBAL TOURISM}

The above has shown the hidden relations of production within the field of tourism from the perspective of economic development. The following section extends this analysis to the contexts of landscapes and culture. Analytical distinctions of these two categories are central to anthropological studies on tourism (cf. Aitchison, Macleod and Shaw 2000; Franklin, Lury and Stacey 2000; Greenwood 1989; Lury 1997; Selwyn 1996; Urry 1990) and include questions of postcolonial (re)appropriations of landscapes and culture, linked to the reassessment of human/non-human, local/global, and subject/object dichotomies (cf. Lash and Urry 1994; Mowforth and Munt 1998; Szerszynski, Heim and Waterton 2003). Tourism is a domain in which interdependencies within the construction of these dichotomies are visible on numerous levels, for example on tourist maps and other visual representations of tourist destinations (cf. Del Casino and Hanna 2000; Szerszynski 2005; Terkenli 2002). As we have argued above, using scale as an analytical tool opens up a new perspective on processes that influence hosts and guests in their ideals, values and perceptions of the world. This calls for a new approach to the nature/culture dichotomy in order to highlight the struggles "in the formation of projects of world transformation" (Tsing 2000: 350).

Undine Frömming's contribution on tourism's impact on the Kilimanjaro region is a particular case in point. The Kilimanjaro region is portrayed as a landscape of enchantment. Frömming outlines the historical emergence of what today are sensational touristic experiences. These experiences are built 
on modernity's idea of "absolute scales"; the grandeur of an everlasting snowwhite peak in the middle of the African continent. But not only European modernisation has reshaped the location. The rituals and narratives of the local population as well as the postcolonial Tanzanian State have also left their imprint on the social construction of its nature/culture dichotomy. Frömming portrays the region as a site of constant, ill-matched struggle involving a multiplicity of actors who dispute over the perception of the relation between nature and culture. Similar struggles take place worldwide as cultural and economic dimensions of environmental politics are negotiated. No matter how successfully such policies are promoted, ideas of landscape or cultural heritage ideally preserved for tourist audiences remain linked to a Eurocentric perception of the world as long as they are carried out within the field of development (cf. Escobar 1992; Ferguson 2005; Franklin 2003). This finds its repercussions in the transformation of the term nature into environment: "Nature is thus made more 'real' when it becomes the 'environment', something that is separate from social and cultural practices and that can be managed to produce discrete, observable and measurable outcomes" (Banerjee 2003: 152-153).

The examples compiled in this dossier show how significant cultural and structural change is transmitted in the world system and how the demands for such cultural and structural change are generated. Here, it is the making and unmaking of "natural" or "cultural" locations that is of importance to the analysis of projects of scale-making. In tourism contexts, research has shown that locations are intertwined through globalist projects of an industry that creates but also fulfils expectations (cf. Smith and Duffy 2003; Waitt 1999; Wang 2000; Wood 2000). These processes build on the aforementioned hidden relations of production. Some of these expectations are presented as new ideas that align the industry with changing demands. One example might be the demand for environmentally friendly tourist resorts set up to attract a natureloving, eco-friendly clientele. Those new resorts are brought into being by standardisations involving "hierarchical scales" such as measuring and mapping. These and other efforts to standardise tourist experiences must be understood as an ordering of the world according to certain categories (Franklin 2003: 212). The question one may ask in the face of several decades of standardisation is how a tourist destination can still be advertised as different? This has been answered in a wider approach often reproducing the nature/culture dichotomy via the analytical categories of sustainability on the one side (cf. Banerjee 2003; Cohen 2002; Cole 2006; Honey 1999; Mowforth and Munt 1998) and heritage on the other (cf. Edensor 1998; Evans-Pritchard 1987; Friedman 1994; Greenwood 1989; Howe 2005). We argue that, instead, a tourist destination needs to be analysed not only as a product of the aforementioned categorisations "eco-friendly" or "sustainable", but as part and parcel of the ideologies of scale that influence the branding of a destination. 
These ideologies can find their repercussions in narratives that tourists share with their friends and family at home. Valerio Simoni's contribution shows how the labelling of cigars by the Cuban government extends into other modes of exchange like informal street deals and reciprocity-based visits to the countryside. The participation of local farmers in the shaping of tourist experiences works as another form of labelling, what Simoni calls a "competing project of scale-making". While scholars have pointed to the fact that debates about local development tend to create unitary perceptions of populations and countries (cf. Banerjee 2003: 151), Simoni demonstrates how, within a given location, parallel projects of scale-making coexist and compete. Both Cuba and the Kilimanjaro are framed by ideologies of scale imposed from the outside and from within. But the aesthetisation of the manufacturing process of cigars, scaled towards nuances and ideas of "the natural" is in fact an experience staged to differ. When the tourists' desire to acquire knowledge of the production process is fulfiled, imaginations of original tobacco growing technologies, as well as of reciprocity-based relationship with farmers emerge that reappear in the tourists" talks about their "great time" (Simoni in this volume). This analysis points to the networked nature of the event, a network in which farmers, tour operators, tourists, landscapes, plants, and everything else that makes a cigar interact. The Kilimanjaro region, on the contrary, is advertised as a place where tourists can experience the spiritual and not the social side of the enlightened self. This trend for self-/nature-based tourism packages is widespread (cf. Potts and Rourke 2000). A comparison of Frömming's and Simoni's case studies opens up yet another dimension: the different kinds of engagement and interaction with the social or the self that tourists set out to find. A central frame for these experiences and respective expectations is the very historicity of the locations. This historicity and the political frame setting interactions influence the distribution of benefits from the tourist economy. Beyond the conventional dichotomy of unpaid and well-paid (cf. Cole 2006: 634), projects of scale-making shape the involvement of villagers, local governments, state-officials and global industries in the construction of culture and landscapes.

But not only in Cuba or Tanzania are culture and landscape developed to please the eye and suit ideologies of scale that create a hierarchy of desires for authentic, preferably endangered, at best nearly extinct culture (cf. Healy 1999: 59). For more than twenty years, studies have documented the ways in which tourism creates exoticized images of the "Other" (Aitchison 2001; Albers and James 1983; Cohen 1993, 1995; Crang 1997; Dann 1996; Enloe 1989). The transformation of societies that become incorporated into circuits of heritage tourism development has led "to the dissolution of clear and immutable boundaries between the very 'ethnicities' that they originally gave rise to, that is, the 'tourist' and the 'resident"' (Bianchi 2003: 17). 
Juraj Buzalka, in his case study on the intersection of revitalised rituals and ethnic tourism in a southeastern Polish region bordering Ukraine, adds to this the notion of "re-scaling ethnicity". His example demonstrates how the Ukrainian minority in the region is incorporated into the Polish State's project of multiculturalism closely connected to the European Union's project of "building Europe" (Shore 2000). In 2004, the "Kupaly Night" ritual was acted out on a neighbourhood scale framed by the wider regional and political setting as a marketable version of Ukrainian identity based on fictions of "ethnic" cooking recipes and music traditions. The organisers of the following year's celebrations in the provincial capital, however, invited the city's mayor to give a speech and "real" Ukrainians from Ukraine to replace the locals of Ukrainian descent as performers of the pagan ritual. Thus, ethnicity was "re-scaled" in terms of real world actors and not only imaginations of community in the region. What was performed in the 2005 version of the ritual was rather a different mode of incorporation (Glick Schiller, Caglar and Guldbrandsen 2006: 614) than an authentic tradition. Buzalka's study shows how scale becomes an integral part within the production of the attractiveness of tourist locations (cf. Howe 2005: 139). Pretes, when writing on Santa-Claus Island in Finland, concludes that this location is a Western product, "a simulacrum, a copied image for which no original exists" (1995: 14). It is exactly this, what any culture on display is about, and particularly so in the realm of tourism, where the key driver is to sell "the affordable dream". ${ }^{13}$ The neighbourhood festes, celebrations of the Canamunt Neighbours' Association, in Ciutat de Mallorca (Morell in this volume) are no exception. Social proximity and traditional practices might have been central motives that drove some people to partake in the festes of the 1980s and 1990s. But their reinvention by a group of local bar owners in 2005 was neither a representation of something original, nor a means to create proximity among the people that inhabit the neighbourhood. Instead, the festes contributed to the re-scaling of the neighbourhood to a regional and European site. Morell's analysis shows how the production of neighbourhood culture and urban landscape are entangled. But not only the meaning of a neighbourhood changes relative to the purpose of its enactment.

The way culture is performed is of central importance to all case studies presented in this volume. Music is a key element both in Buzalka's and Morell's examples that demonstrate how a culture is staged to suit tourist demands (cf. Cole 2006). But 35 years after MacCannell (1973), the stage has itself become a crucial device. Those on it are approved by the tourism industry and can proudly present themselves as authentic representatives of a "local culture". Like in the realm of "world music" where multilayered struggles about staged exotism and difference take place (cf. Stokes 2004; Wergin 2007), the actors 
on stage have to fulfil certain criteria in order to be recognisable and to gain support from the industry. Such "local actors" thus follow the demand for a traditionalist, or ex-primitivist way of being, based on constructivist scales not informed by actual difference but by complex modes of self-exotisation via musical practice (MacCannell 1992; Wergin 2009a, 2009b). These exotic performers produce the globalist image of multiculturalism. The appeal of this global image has grown since enlightenment's fall for modernist romanticism and is vividly observable in ideologies of scale that produce notions and images of authentic nature and culture.

\section{CONCLUSION}

Tourism nurtures complexity in the sense that different groups of people work in and for the industry and that it creates mobility for those involved in the setting up of tourist experiences. But tourism, of course, also entails diverse groups of people travelling for recreational purposes. The papers collected in this dossier extend the categories of analysis at hand in the anthropology of tourism (cf. Smith 1978; Smith and Brent 2001, for a range of categorisation) by looking at the wider historical and political frames that generate types of tourism: there are those who seek aesthetics shaped by European enlightenment (Kilimanjaro), those attracted by Eastern European politics of postcommunist multiculturalism (Poland), there are the inhabitants and visitors of a neighbourhood subject to Mediterranean heritage conservation (Ciutat de Mallorca), or those that follow the production chain of cigars in a world staged to appear free from capitalist constraints (Cuba). Such diversity justifies the demand for a fundamental critique of the imaginary set up by globalisation discourse and strategy (Tsing 2000: 334). Scale, in this respect, has to be considered as more than a framework - it is what makes the frame work. Local environments are shaped in order to fulfil global demands. Projects of scale-making frame the ways in which people, landscapes and cultures are marketed and labelled: be it the "natural" Cuban tobacco industry (see Simoni), the engagement with the "enchanted" Kilimanjaro region (see Frömming), the specific qualities of a Mallorcan neighbourhood (see Morell), or self-exoticising rituals at the Polish-Ukrainian border (see Buzalka).

What so far has been missing in our discussion is the famously coined "tourist gaze". Although Urry (1990) built this concept on a multiplicity of gazes that are determined by non-tourist activities (1990: 1-2), his work has been criticised as a top-down perspective privileging the tourist's perspective over those of others active in the industry. We have argued, however, that an even more nuanced relationship between hosts and guests needs to be evoked. This must incorporate a multiplicity of gazes at work on all strata of the tourism industry (cf. Franklin and Crang 2001; Smith and Brent 2001). 
Our account of projects of scale-making and ideologies of scale actively pursued in tourism goes hand in hand with this call for a re-consideration of particular gazes that are, for example, concerned with "local" tradition and landscapes, while simultaneously informed by standardised strategies of development, marketing and control. Landscape and culture are influenced by gazes from all those active in developing, staging and consuming tourism. Beyond the perspective of tourism as the "mirror of society" and the dualistic distinction of work and leisure, a place visited is both "the exotic" and the "ordinary" at the same time. The tourist's search for "the affordable dream" (see above) is framed by non-tourist activities like work and household life as well as by different preferences for projects of scale-making. MacCannell has emphasised the historical dimension in the production of tourist experiences (MacCannell 2001: 25). Along with both the historical and the economic dimension of staged experiences, competing projects of scale-making produce ways in which tourists, locals and anthropologists can gaze at a location. A thorough analysis of these projects reveals conflicts and alliances among local populations, national politics, tourists and international companies and organisations in the making of a tourist destination. Gazes in this model become a matrix of the past, present and future production of tourist sites, and of the different actors involved: tourists, entrepreneurs, elderly women who are engaged in fer barri, politicians, local farmers, bar owners, cigar manufacturers, participants in pagan rituals, environmental preservationists. Scale used as an analytical tool allows us to "gaze" underneath these projects and - to refer to the quote from MacCannell in the introductory remarks again - to understand what has been arranged for us and what is still in the process of being arranged.

This paper has been concerned with the temporal and spatial dimensions of tourism. The tourist industry has been portrayed as embedded in wider projects of development and the making and unmaking of lifestyle-like orientations of being in the world. We have suggested abandoning "absolute" dichotomies such as local versus global, or small versus large, because the constructed nature of tourism locations instead necessitates the introduction of a meta-perspective that entails competing and contested projects of scale-making. This meta-perspective reveals hidden relations of production entangled within the repositioning of locations across time and space implemented by both politics of development and enactments and stagings of culture. In the realm of tourism, such re-scalings (Uitermark 2002) are driven by a multiplicity of expectations working on absolute, hierarchical and constructivist ideologies of scale. The stubbornness of the German right wing civil society movement during the 2006 World Cup demonstrates that as soon as the anthropology of tourism returns "home", it might be difficult to perceive of tourism as "the perpetrator" and host communities as the "victims" anthropologists should aim to support. The same is to be said about Polish villagers who lament the 
re-scaling of "their" pagan ritual, about the Chagga deprived of "holy" Kilimanjaro, who lament their spiritual suffering, informal cigar dealers in Cuba who lament the politics of standardisation by the socialist state, or the local bar owners who want to gentrify the old centre of Ciutat de Mallorca.

The papers collected in this dossier as well as our introduction were first presented at the annual conference of the Association of Social Anthropologists of the UK and the Commonwealth in London in 2007 entitled "Thinking through Tourism". In the final discussion to this conference many speakers expressed their growing discontent with the ever-increasing body of anthropological literature on "staged culture" and "authenticity" in global tourism. Projects of scale-making have so far barely been taken into consideration as a point of departure in anthropology. Their analysis is important because it tackles the notion of places as "frozen in time" which is the backbone of ideologies of reciprocal exchange, projects of development and a performative reification of landscapes and culture. Tourism is a product of modern Western society (Chambers 2000; MacCannell 1999 [1976]; Urry 1990). But as a global industry, it is an arena with multiple gazes at work, which the whole world actively or passively participates in. It is up to the anthropologist to decide what power struggles and hidden relations of production to highlight and thus which gazes to question. When the ideologies of scale that produce and inform socio-political and economic networks are accounted for, light can be shed on the complex transformations of spaces, people, goods, interests and ideas in a "contextually specific [and] yet theoretically self-reflexive" manner (Brenner 2001: 605). Our proposed point of departure for the engagement with the texts in this dossier is therefore to use scale as a device which is of elementary importance to the understanding of a transformation in which the politics of nature, culture and the economy intertwine.

\section{REFERENCES}

ABRAM, Simone, Jackie WALDREN, and Don MACLEOD (eds.), 1997, Tourists and Tourism: Identifying with People and Places. Oxford, Berg Publishers.

ADAMS, Kathleen, 2004, "The genesis of touristic imagery: politics and poetics in the creation of a remote Indonesian island destination”, Tourist Studies, 4 (2): 115-135.

AKYeAmPOng, Oheneba Akwesi, 1996, Tourism and Regional Development in Sub-Saharan Africa, Stockholm, University of Stockholm, PhD dissertation.

AITCHISON, Cara, 2001, "Theorizing other discourses of tourism, gender and culture: can the subaltern speak (in tourism)?", Tourist Studies, l (2): 133-147. 
AITCHISON, Cara, Nicola MACLEOD, and Stephen SHAW (eds.), 2000, Leisure and Tourism Landscapes: Social and Cultural Landscapes. London and New York, Routledge.

ALBERS, Patricia, and William JAMES, 1983, “Tourism and the changing photographic image of the Great Lakes Indians", Annals of Tourism Research, 10: 123-148.

ASPELIN, Paul, 1978, Tourism and Economic Change. Williamsburg, College of William and Mary.

BACA, George, 2005, "Legends of fordism: between myth, history, and foregone conclusions", in Bruce Kapferer (ed.), The Retreat of the Social: The Rise and Rise of Reductionism. New York and Oxford, Berghahn Books, 31-46.

BANERJEE, Subhabrata Bobby, 2003, "Who sustains whose development? Sustainable development and the reinvention of nature", Organization Studies, 24 (1): 143180 .

BENEDICT, Burton, 1966, "Sociological characteristics of small territories and their implications for economic development", in M. Banton (ed.), The Social Anthropology of Complex Societies. London, Tavistock Publications, 23-36.

BERREMAN, Gerald, 1978, "Scale and social relations", Current Anthropology, 19 (2): 225 245.

BIANCHI, Raoul, 2003, "Place and power in tourism development: tracing the complex articulations of community and locality", PASOS: Revista de Turismo y Patrimonio Cultural, 1 (1): 13-32.

BOISSEVAIN, Jeremy, 1996, Coping with Tourists: European Reactions to Mass Tourism. Oxford, Berghahn Books.

BRENNER, Neil, 2001, "The limits to scale? Methodological reflections on scalar structuration”, Progress in Human Geography, 25 (4): 591-614.

BURNS, Peter, 1999, An Introduction to Tourism and Anthropology. London, Routledge.

BUSCH, Lawrence, 2000, "The moral economy of grades and standards", Journal of Rural Studies, 16: 273-283.

CARRIER, James, 1992, “Occidentalism: the world turned upside-down”, American Ethnologist, 19 (2): 195-212.

CHALFIN, Brenda, 2006, "Global customs regimes and the traffic in sovereignty: enlarging the anthropology of the State”, Current Anthropology, 47 (2): 243-276.

CHAMBERS, Erve, 2000, Native Tours: The Anthropology of Travel and Tourism. Prospect Heights, IL, Waveland.

CLANCY, Michael, 2001, Exporting Paradise: Tourism and Development in Mexico. New York, Pergamon Press.

CLIFFORD, James, 1997, Routes, Travel and Translation in the Late Twentieth Century. Cambridge, MA, Harvard University Press.

COHEN, Eric, 1993, "The study of touristic images of native people: mitigating the stereotype of a stereotype", in Douglas Pearce and Richard Butler (eds.), Tourism Research: Critiques and Challenges. London, Routledge, 36-69.

— 1995 , "The representation of Arabs and Jews on postcards in Israel", History of Photography, 19 (3): 210-220.

— 2002 , "Authenticity, equity and sustainability in tourism", Journal of Sustainable Tourism, 10 (4): 267-276.

COLE, Stroma, 2006, "Information and empowerment: the keys to achieving sustainable development", Journal of Sustainable Tourism, 14 (6): 629-644. 
COlES, Tim, and Dallen TIMOTHY, 2004, Tourism, Diasporas and Space. London, Routledge.

CRANG, Mike, 1997, "Picturing practice: research through the tourist gaze", Progress in Human Geography, 21 (3): 359-373.

CRICK, Malcolm, 1989, "Representations of international tourism in the social sciences: sun, sex, sights, savings, and servility", Annual Review of Anthropology, 18: 307-344.

DALTON, George, 1965, "Primitive money", American Anthropologist, 67 (1): 44-65.

DAMON, Frederick, 1990, From Muyuw to the Trobriands: Transformations Along the Northern Side of the Kula Ring. Tucson, AZ, University of Arizona Press.

_- 1993, "Representation and experience in Kula and Western exchange spheres (or, Billy)”, Research in Economic Anthropology, 14: 235-254.

DANN, Graham, 1996, "The people of tourist brochures", in Tom Selwyn (ed.), The Tourist Image: Myths and Myth-Making in Tourism. Chichester, John Wiley and Sons, 61-81.

DE KADT, Emanuel, 1979, Tourism: Passport to Development? Perspectives on the Social and Cultural Effects of Tourism in Developing Countries. New York, OUP.

DEL CASINO, Vincent, and Stephen HANNA, 2000, "Representation and identity in tourism map spaces”, Progress in Human Geography, 24 (1): 23-46.

DUVAL, David Timothy, 2007, Tourism and Transport: Modes, Networks and Flows. Clevedon, Channel View Publications.

EDElman, Marc, and Angelique HAUGERUd, 2005, The Anthropology of Development and Globalization: From Classical Political Economy to Contemporary Neoliberalism. Malden, MA, and Oxford, Basil Blackwell Publishing Ltd.

EDENSOR, Tim, 1998, Tourists at the Taj: Performance and Meaning at a Symbolic Site. London and New York, Routledge.

—, 2000, "Staging tourism: tourists as performers", Annals of Tourism Research, 27: 322-344.

ENloE, Cynthia, 1989, Bananas, Beaches, and Bases: Making Feminist Sense of International Politics. London, Pandora.

ESCOBAR, Arturo, 1992, "Imagining a post-development era: critical thought, development and social movements", Social Text, 31 (32): 20-56.

EVANS-PRITCHARD, Deirdre, 1987, “The portal case: authenticity, tourism, traditions, and the law", The Journal of American Folklore, 100 (397): 287-296.

_- 1989, "How 'they' see 'us': native american images of tourists", Annals of Tourism Research, 16 (1): 89-105.

FAUBION, James D., 1993, "History in anthropology”, Annual Review of Anthropology, 22: $35-54$

FERGUSON, James, 2005, “Decomposing modernity: history and hierarchy after development”, in A. Loomba et al. (eds.), Postcolonial Studies and Beyond. Durham, Duke University Press, 166-181.

FRANKLIN, Adrian, 2003, “The tourist syndrome: an interview with Zigmunt Bauman”, Tourist Studies, 3 (2): 205-217.

FRANKLIN, Adrian, and Mike CRANG, 2001, "The trouble with tourism and travel theory", Tourist Studies, 1 (1): 5-22.

FRANKLIN, Sarah, Celia LURY, and Jackie STACEY, 2000, Global Nature, Global Culture. London, Sage Publications.

FRIEDMAN, Jonathan, 1994, Cultural Identity and Global Process. London, Sage Publications. 
GLICK SCHILLER, Nina, Ayse CAGLAR, and Thaddeus GULDBRANDSEN, 2006, "Beyond the ethnic lens: locality, globality, and born-again incorporation", American Ethnologist, 33 (4): 612-633.

GODELIER, Maurice, 1999, Das Rätsel der Gabe: Geld, Geschenke, Heilige Objekte. München, Verlag C.H. Beck.

GORDON, Ian, and Brian GOODALL, 2000, "Localities and tourism”, Tourism Geographies, 2 (3): 290-311.

GRABURN, Nelson, and Diane BATHEL-BOUCHIER, 2001, "Relocating the tourist", International Sociology, 16 (2): 147-158.

GREEN, Sarah, Penny HARVEY, and Hannah KNOX, 2005, "Scales of place and networks: an ethnography of the imperative to connect through information and communications technologies", Current Anthropology, 46 (5): 805-826.

GREENWOOD, David, 1977, "Tourism as an agent of change: a Spanish Basque case", Annals of Tourism Research, 3: 128-142.

—, 1989, "Culture by the pound: an anthropological perspective on tourism as cultural commoditisation", in Valene Smith (ed.), Hosts and Guests: The Anthropology of Tourism. Philadelphia, University of Pennsylvania Press, 171-185.

Gregory, Chris, 1997, Savage Money: The Anthropology and Politics of Commodity Exchange. Amsterdam, Harwood Academic Publishers.

GUPTA, Akhil, and James FERGUSON, 1997, "Discipline and practice: 'the field' as site, method, and location in anthropology", in Akhil Gupta and James Ferguson (eds.), Anthropological Locations: Boundaries and Grounds of a Field Science. Berkeley, University of California Press, 1-46.

HALL, C. Michael, 2005, Tourism: Rethinking the Social Science of Mobility, Harlow, Pearson Education.

HALL, C. Michael, and S.J. PAGE, 2002, The Geography of Tourism and Recreation. London, Routledge, $2^{\text {nd }}$ edition.

HANNAM, Kevin, 2006, "Heritage tourism and development III: performances, performativities and mobilities”, Progress in Development Studies, 6 (3): 243-249.

HEALY, Chris, 1999, "White feet and black trails: travelling cultures at the Lurujarri trail", Postcolonial Studies, 2 (1): 55-73.

HEIMTUN, Bente, 2007, "Depathologizing the tourist syndrome: tourism as social capital production", Tourist Studies, 7 (3): 27 1-293.

HONEY, Martha, 1999, Ecotourism and Sustainable Development: Who Owns Paradise? Washington, DC, Island Press.

HOWE, Leo, 2005, The Changing World of Bali: Religion, Society and Tourism. London, Routledge.

KEARNEY, Michael, 1995, “The local and the global: the anthropology of globalization and transnationalism”, Annual Review of Anthropology, 24: 547-565.

LASH, Scott, and John URRY, 1994, "Mobility, modernity and place", in Scott Lash and John Urry (eds.), Economies of Signs and Space. London, Sage Publications, 252 278.

LEACH, Jerry Wayne, 1983, The Kula: New Perspectives on Massim Exchange. Cambridge, Cambridge University Press.

LEPP, Andrew, 2007, "Residents' attitudes towards tourism in Bigodi village, Uganda”, Tourism Management, 28: 876-885. 
LEYS, Colin, 1996, The Rise and Fall of Development Theory. Nairobi, Bloomington, IN, and London, EAEP, Indiana University Press and James Currey.

LI, Yiping, 2003, "Heritage tourism: the contradictions between conservation and change", Tourism and Hospitality Research, 4 (3): 247-261.

LURY, Celia, 1997, "The objects of travel", in C. Rojek and J. Urry (eds.), Touring Cultures. Abingdon, Routledge, 75-95.

MACCANNELL, Dean, 1973, "Staged authenticity: arrangements of social space in tourist settings”, The American Journal of Sociology, 79 (3): 589-603.

—, 1992, Empty Meeting Grounds: The Tourist Papers. London, Routledge.

—, 1999 [1976], The Tourist: A New Theory of the Leisure Class. Berkeley, University of California Press.

—, 2001, "Tourist agency", Tourist Studies, 1 (1): 23-37.

MANSON, Steven, 2008, "Does scale exist? An epistemological scale continuum for complex human-environment systems”, Geoforum, 39: 776-788.

MCKEAN, Philip, 1978, "Towards a theoretical analysis of tourism: economic dualism and cultural involution in Bali”, in Valene Smith (ed.), Hosts and Guests: The Anthropology of Tourism. Philadelphia, University of Pennsylvania Press, 93-108.

MEETHAN, Kevin, 2001, Tourism in Global Society: Place, Culture, Consumption. Basingstoke, Palgrave.

MILlER, Daniel, 1994, Modernity, an Ethnographic Approach: Dualism and Consumption in Trinidad. Oxford, Berg Publishers.

MITCHELL, Lisle, 1984, "Tourism research in the United States: a geographic perspective", GeoJournal, 9 (1): 5-15.

MITCHELL, T., 1995, "Worlds apart: an Egyptian village and the international tourism industry", Middle East Report, 196: 8-1 1 +23.

MONTANARI, Armando, and Allan WILLIAMS, 1995, European Tourism: Regions, Spaces and Restructuring. Chichester, John Wiley and Sons.

MOWFORTH, Martin, and Ian MUNT, 1998, Tourism and Sustainability: A New Tourism in the Third World. London and New York, Routledge.

NASH, Dennison, 1989, "Tourism as a form of imperialism", in Valene Smith (ed.), Hosts and Guests: The Anthropology of Tourism. Philadelphia, University of Pennsylvania Press, 33-48.

—, 2001, Anthropology of Tourism. New York, Pergamon Press, $2^{\text {nd }}$ edition.

NEVELING, Patrick, 2006, "Spirits of capitalism and the de-alienation of workers: a historical perspective on the Mauritian garment industry", working paper GZAA, MLU Halle-Wittenberg. Available at <http://www.scm.uni-halle.de>.

— - forthcoming, "A periodisation of globalisation according to the Mauritian integration into the international sugar commodity chain (1825-2005)", Commodities of Empire, Working Paper Series.

PARRY, Jonathan, 1986, “The gift, the Indian gift, and the 'Indian gift'”, Man, 21 (3): 453-473. POLANYI, Karl, 1957, The Great Transformation. Boston, Beacon Press.

POTTS, Thomas, and Thomas ROURKE, 2000, "Nature-based heritage tourism enterprises: guidelines for success", available at < http://www.strom.clemson.edu/publications/Potts/nbt2000.pdf> (last accessed 31/08/2009).

PRETES, Michael, 1995, "Postmodern tourism: the Santa Claus industry", Annals of Tourism Research, 22 (1): 1-15. 
RANKIN, Katharine, 2003, "Anthropologies and geographies of globalization", Progress in Human Geography, 27 (6): 708-734.

ROJEK, Chris, and John URRY, 1997, Touring Cultures: Transformation of Travel and Theory. London and New York, Routledge.

SAARINEN, Jarkko, 2004, "Destinations in change: the transformation process of tourist", Tourist Studies, 4 (2): 161-179.

SASSEN, Saskia, 2000, Cities in a World Economy. Thousand Oaks, CA, Pine Forge Press, $2^{\text {nd }}$ edition.

SCHLEHE, Judith, 2003, "Ethnologie des Tourismus: zur Entgrenzung von Feldforschung und Reise", Peripherie: Zeitschrift für Politik und Ökonomie in der Dritten Welt, 89: 31-47.

SCHNEPEL, Burkhard, 2008a, “Die Globalisierung des Strandes: das Beispiel Mauritius”, in V. Gottowik, H. Jebens und E. Platte (eds.), Zwischen Aneignung und Verfremdung: Ethnologische Gratwanderungen. Frankfurt am Main, Campus Verlag, 489-512.

— 2008 b, “'Finger weg von unserem Strand': Tourismus auf einer multikulturellen 'Paradiesinsel' (Mauritius)”, Arbeitspapiere zur Sozialanthropologie. Wien, Österreichische Akademie der Wissenschaft, 4, at <http://www.oeaw.ac.at/>.

SCOTT, James C., 2003, The Moral Economy of the Peasant Rebellion and Subsistence in Southeast Asia. New Haven, CT, London, Yale University Press.

SELWYN, Tom, 1996, The Tourist Image: Myths and Myth-Making in Tourism. Chichester, John Wiley and Sons.

SHORE, Cris, 2000, Building Europe the Cultural Politics of European Integration. London, Routledge.

SIDAWAY, James. D., 2007, "Spaces of postdevelopment", Progress in Human Geography, 31 (3): 345-361.

SILVER, Beverly Judith, 2003, Forces of Labor: Workers' Movements and Globalization since 1870. Cambridge and New York, Cambridge University Press.

SIMONI, Valerio, 2008, “'Riding' diversity: Cubans'/Jineteros' uses of 'nationality-talks' in the realm of their informal encounters with tourists", in Peter Burns and Marina Novelli (eds.), Tourism Development: Growth, Myths and Inequalities. Wallingford, Cambridge, MA, CAB International, 68-84.

SMITH, Mike, and Rosaleen DUFFY, 2003, The Ethics of Tourism Development, London, Routledge.

SMITH, Neil, 1992, "Contours of a spatialized politics: homeless vehicles and the production of geographical scale", Social Text, 33: 55-81.

SMITH, Valene (ed.), 1978, Hosts and Guests: The Anthropology of Tourism. Philadelphia, University of Pennsylvania Press.

SMITH, Valene, and Maryann BRENT (eds.), 2001, Hosts and Guests Revisited: Tourism Issues of the $21^{\text {st }}$ Century. New York, Cognizant Press.

STOKES, Martin, 2004, "Music and the global order", Annual Review of Anthropology, 33: 47-72.

STRONZA, Amanda, 2001, "Anthropology of tourism: forging new ground for ecotourism and other alternatives", Annual Review of Anthropology, 30: 261-283.

SWYNGEDOUW, Erik, 2004, "Globalisation or 'glocalisation'? Networks, territories and rescaling”, Cambridge Review of International Affairs, 17 (1): 25-48.

SZERSZYNSKI, Bronislaw, 2005, Nature, Technology and the Sacred. Malden, Basil Blackwell Publishing. 
SZERSZYNSKI, Bronislaw, Wallace HEIM, and Claire WATERTON (eds.), 2003, Nature Performed: Environment, Culture and Performance. Oxford, Basil Blackwell Publishing.

TERKENLI, Theano, 2002, "Landscapes of tourism: towards a global cultural economy of space?”, Tourism Geographies, 4 (3): 227-254.

TROUILLOT, Michel-Rolph, 2003, Global Transformations: Anthropology and the Modern World. New York, Palgrave.

TSING, Anna, 2000, “The Global Situation”, Cultural Anthropology, 15 (3): 327-360.

UITERMARK, Justus, 2002, “Re-scaling, 'scale fragmentation' and the regulation of antagonistic relationships”, Progress in Human Geography, 26: 743-765.

URRY, John, 1990, The Tourist Gaze: Leisure and Travel in Contemporary Societies. London, Sage Publications.

WAITT, Gordon, 1999, “Naturalising the 'primitive': a critique of marketing Australia's indigenous peoples as 'hunter-gatherers", Tourism Geographies, I (2): 142-163.

WALDREN, Jacqueline, 1997, "We are not tourists, we live here", in Simone Abram, Jackie Waldren and Don Macleod, Tourists and Tourism: Identifying with People and Places. Oxford, Berg Publishers, 51-70.

WANG, Ning, 2000, Tourism and Modernity, Amsterdam, Pergamon Press.

WEINER, Annette Barbara, 1988, The Trobrianders of Papua New Guinea. New York, Holt, Rinehart and Winston.

WERGIN, Carsten, 2007, "World music: a medium for unity and difference?”, EASA Media Anthropology Network, at < http://www.philbu.net/media-anthropology/wergin_worldmusic.pdf $>$ (accessed 15/01/2009).

—, 2009a, Kréol Blouz: Musikalische Inszenierungen von Identität und Kultur. Köln, Boehlau.

—, 2009b, "T'shéga, shéga, séga...: music, identity and creolisation on Réunion island", in Vinesh Hookoomsing, R. Ludwig and B. Schnepel (eds.), Multiple Identities in Action: Mauritius and Some Antillean Parallelisms. Frankfurt a. M., Peter Lang, 255-274.

WILLIAMS, Allan, and C. Michael HALL, 2000, “Tourism and migration: new relationships between production and consumption", Tourism Geographies, 2 (1): 5-27.

WOOD, Ron, 2000, "Caribbean cruise tourism: globalisation at sea", Annals of Tourism Research, 27 (2): 345-370.

YAMASHITA, Shinji, 2003, Bali and Beyond: Explorations in the Anthropology of Tourism. New York, Berghahn Books.

YOUNG, Martin, 1999, “The relationship between tourist motivations and the interpretation of place meanings", Tourism Geographies, 1 (4): 387-405.

ZIAI, Aram, forthcoming, "From development discourse to the discourse of globalisation: changing forms of knowledge about change in North-South relations and their political consequences", in Patrick Neveling (ed.), Sociologus, Special Issue: Notions of Change: Development, History, Social Transformation.

Projectos de configuração de escala: novas perspectivas para a antropologia do turismo - Patrick Neveling - Institute for Social Anthropology/Historical Institute, University of Bern, Suíça • patrick.neveling@hist.unibe.ch .• Carsten Wergin • Graduate School Society and Culture in Motion (SCM), Martin-Luther-University Halle-Wittenberg, Alemanha carsten.wergin@ scm.uni-halle.de 
A escala foi recentemente incorporada na antropologia social como unidade de análise e ferramenta heurística. Este artigo centra-se naquilo que Tsing (2000) definiu como "projectos de configuração de escala" e nos respectivos "modos de incorporação" tal como explorados por Glick Schiller, Caglar e Guldbrandsen (2006), destacando a sua aplicabilidade à antropologia do turismo. Na medida em que o turismo é uma das indústrias centrais para a configuração das ideias actuais acerca do que é global e do que é local, a escala, enquanto instrumento teórico e metodológico, adequa-se de forma ideal ao estudo deste campo. Aspectos nucleares da pesquisa antropológica sobre o turismo, como a economia política desta indústria, a sua influência na percepção de paisagens e culturas, ou ainda a controversa noção de autenticidade, são aqui reconsiderados. Defendemos que as principais falhas do debate sobre a globalização, como o futurismo de fundo teleológico, as noções eufemísticas sobre a circulação económica e a mistura entre debates científicos e comuns, informam, simultaneamente, a indústria turística e demasiados estudos antropológicos sobre o turismo. Em alternativa, e à luz das contribuições reunidas neste dossiê, este artigo desenvolve um quadro analítico que destaca as relações de produção ocultas nas economias turísticas e o impacte de projectos de configuração de escala na construção de paisagens e culturas.

PALAVRAS-CHAVE: cultura, globalização, história, economia política, escala, turismo. 